\title{
Biochar from swine manure solids: influence on carbon sequestration and Olsen phosphorus and mineral nitrogen dynamics in soil with and without digestate incorporation
}

\author{
Rosa Marchetti, ${ }^{1}$ Fabio Castelli,, Anna Orsi, ${ }^{1}$ Lidia Sghedoni,, Davide Bochicchio' \\ ${ }^{1}$ C.R.A., Unità di Ricerca per la Suinicoltura, San Cesario sul Panaro, MO; ${ }^{2}$ C.R.A., Centro di Ricerca \\ per la Viticoltura, Azienda sperimentale di Bovolone, VR, Italy
}

\begin{abstract}
Interest in biochar (BC) has grown dramatically in recent years, due mainly to the fact that its incorporation into soil reportedly enhances carbon sequestration and fertility. Currently, BC types most under investigation are those obtained from organic matter $(\mathrm{OM})$ of plant origin. As great amounts of manure solids are expected to become available in the near future, thanks to the development of technologies for the separation of the solid fraction of animal effluents, processing of manure solids for BC production seems an interesting possibility for the recycling of $\mathrm{OM}$ of high nutrient value. The aim of this study was to investigate carbon (C) sequestration and nutrient dynamics in soil amended with $\mathrm{BC}$ from dried swine manure solids. The experiment was carried out in laboratory microcosms on a silty clay soil. The effect on nutrient dynamics of interaction between $\mathrm{BC}$ and fresh digestate obtained from a biogas plant was also investigated to test the hypothesis that BC can retain nutrients. A comparison was made of the following treatments: soil amended with swine manure solids (LC), soil amended with charred swine manure solids (LT), soil amended with wood chip (CC), soil amended with charred wood chip (CT), soil with no amendment as control (Cs), each one of them with and without incorporation of digestate (D) for a total of 10 treatments. Biochar was obtained by treating OM (wood chip or swine manure) with moisture content of less than $10 \%$ at $420^{\circ} \mathrm{C}$ in anoxic conditions. The $\mathrm{CO}_{2}-\mathrm{C}$ release and organic $\mathrm{C}$, available phosphorus $(\mathrm{P})$ (Olsen $\mathrm{P}, \mathrm{P}_{\mathrm{Ols}}$ ) and
\end{abstract}

Correspondence: Dr. Rosa Marchetti, C.R.A., Unità di Ricerca per la Suinicoltura, Via Beccastecca 345, 41018 San Cesario sul Panaro (M0), Italy. Tel. +39.059.926268 - Fax: +39.059.928371.

E-mail: rosa.marchetti@entecra.it

Key words: biochar, emissions, manure, nitrogen, phosphorus.

Received for publication: 4 0ctober 2011.

Accepted for publication: 24 March 2012.

CC Copyright R. Marchetti et al., 2012

Licensee PAGEPress, Italy

Italian Journal of Agronomy 2012; 7:e26

doi:10.4081/ija.2012.e26

This article is distributed under the terms of the Creative Commons Attribution Noncommercial License (by-nc 3.0) which permits any noncommercial use, distribution, and reproduction in any medium, provided the original author(s) and source are credited. inorganic (ammonium+nitrate) nitrogen $(\mathrm{N})\left(\mathrm{N}_{\min }\right)$ contents at the start and three months after the start of the experiment were measured in the amended and control soils. After three months of incubation at $30^{\circ} \mathrm{C}$, the $\mathrm{CO}_{2}-\mathrm{C}$ emissions from soil with $\mathrm{BC}$ (CT and $\mathrm{LT}, \pm \mathrm{D}$ ) were the same as those in the control soil (Cs) and were lower than those in the soils with untreated amendments (CC and LC, $\pm \mathrm{D})$. The organic $\mathrm{C}$ content decreased in $\mathrm{CT}$ and $\mathrm{LT}$ to a lesser extent than in $\mathrm{CC}$ and LC. In soils with $\mathrm{D}(+\mathrm{D})$, the $\mathrm{CO}_{2}-\mathrm{C}$ emissions were equal to or higher than those in soils without (-D). The $\mathrm{N}_{\min }$ content increased in all treatments; the $\mathrm{P}_{0 l s}$ content decreased in the $+\mathrm{D}$ treatments. The incorporation of $\mathrm{BC}$ into soil, by reducing $\mathrm{CO}_{2}$ emissions, actually contributes to $\mathrm{C}$ sequestration without modifying $\mathrm{N}$ availability for crops. For a given $\mathrm{N}$ content, the $\mathrm{BC}$ from swine manure solids supplies much more $\mathrm{P}$ than the non-treated $\mathrm{OM}$ and, therefore, represents an interesting source of $P$ for crops.

\section{Introduction}

Biochar (BC) is the product of thermal degradation of organic materials in the absence of air. It is distinguished from charcoal by its use as soil amendment (Lehmann and Joseph, 2009). Interest in BC has grown dramatically in recent years (Sohi et al., 2010), especially since it was reported that its incorporation into soil improves carbon (C) sequestration and soil fertility (Lehmann et al., 2006; Steiner et al., 2007). The substitution of chemical fertilizers by BC has been proposed as a possible way to contrast fossil fuel resource depletion, in a transition process towards a non-fossil fueled food system (Heinberg and Bomford, 2009).

Lehmann et al. (2006), in a global analysis on $\mathrm{C}$ sequestration in terrestrial ecosystems, reported that conversion of biomass $\mathrm{C}$ to $\mathrm{BC}$ leads to the sequestration of approximately $50 \%$ of the initial $\mathrm{C}$, whereas only $3 \%$ could be retained after burning, and less than $10-20 \%$ after 5-10 years of biological decomposition. This kind of treatment may, therefore, allow a more stable $\mathrm{C}$ reserve to be constituted in soil than biomass burning or direct application of plant residues to soil. Biochar soil management systems can deliver tradable $\mathrm{C}$ emission reduction because sequestered $\mathrm{C}$ is easily traced and verifiable. Some authors have speculated that, by 2100 , global BC sequestration could be similar in magnitude to the total current global fossil fuel emissions. More cautious estimates predict that global-scale BC sequestration could reduce atmospheric carbon dioxide levels by 10 ppm by 2050 and 37 ppm by 2100 (Collison et al., 2009).

Fertilizing properties of $\mathrm{BC}$ have been evaluated mainly for $\mathrm{BC}$ obtained from plant material with low moisture content (the optimal moisture content for BC production being less than 10\%; Lehmann 
and Joseph, 2009) and, therefore, more suitable for charring because it does not require any prior dehydration. Charring treatment gives higher $\mathrm{BC}$ yields and is, therefore, more advantageous for the obtaining of $\mathrm{BC}$ to be used as fertilizer (Cantrell et al., 2008). Among animal effluents, poultry litter has a low moisture content and is, therefore, the most frequently tested raw material as BC source (Chan et al., 2008). Recently, a study was carried out on thermal decomposition kinetics of swine solids (Ro et al., 2009). However, research on the fertilizing quality of $\mathrm{BC}$ obtained from animal effluents is still scarce (Oenema, 2010; Sørensen and Rubaek, 2010). Marchetti et al. (2010), in a preliminary study aiming to evaluate the potential of pyrolysis of swine solids as a technique for producing energy and fertilizers, compared the influence of process conditions on $\mathrm{BC}$ yield and nutrient content, and identified the best time-temperature combinations for yield optimization.

In recent years, the implementation of European directives for the control of the environmental impact of agricultural practices has led to huge cost increases for the management of animal manure. The need to safeguard the farmer's income by reducing costs has provided a substantial stimulus to research on manure treatments, and especially the development of technologies for the separation of the solid fraction (Burton, 2007). Separation of solids is applied both to fresh manure, obtained from routine cleaning out of the pig farm, and to digestate, that is the sludge resulting from manure digestion for biogas production. On the one hand, should these technologies become economically feasible, the treatment of the swine solid fraction for $\mathrm{BC}$ production may become an interesting solution for successful waste management. On the other hand, the thermal treatment (of whatever kind) produces energy-rich final products that can be utilized for the combined production of heat and electric power, with possible recovery of the treatment costs (Sánchez et al., 2007). The aim of this study was to evaluate in the laboratory the suitability of $\mathrm{BC}$ from swine solids when incorporated into soil to improve soil $\mathrm{C}$ sequestration and fertility. Specifically, the $\mathrm{CO}_{2}-\mathrm{C}$ emissions and changes in soil organic $\mathrm{C}$ $\left(\mathrm{C}_{\text {org }}\right)$, mineral nitrogen $\left(\mathrm{N}_{\min }\right)$ and available phosphorus $(\mathrm{P})\left(\mathrm{P}_{0 \mathrm{ls}}\right)$ in soil after $\mathrm{BC}$ incorporation were measured in laboratory microcosms for a 3-month incubation period. Wood chip, the material most frequently used today for BC production, was also included in the experiment as a reference material. Furthermore, we considered the interaction effect of $\mathrm{BC}$ and digestate when incorporated together into soil on $\mathrm{CO}_{2}$-C emissions and changes in soil $\mathrm{C}, \mathrm{N}$ and $\mathrm{P}$ contents, to consider the hypothesis made by some authors (Liang et al., 2006) that BC is able to sequester soil nutrients thanks to its high cation-exchange capacity. In fact, digestate, the by-product of anaerobic digestion, still contains most of the nutrients which were present in the initial raw material, especially N. Research is now, therefore, focusing on the use of digestate as fertilizer. The simultaneous utilization of $\mathrm{BC}$ and digestate could delay the release of digestate-deriving $\mathrm{N}$ into the soil, reduce its polluting effect and extend nutrient availability for crops over time.

\section{Materials and methods}

\section{Laboratory microcosms}

Carbon dioxide release from a silty soil amended with different materials was determined in 40-mL scintillation vials during a 3-month incubation period. Mineral $\mathrm{N}$ and $\mathrm{P}_{\text {Ols }}$ contents in soil were also measured at the beginning and at the end of the incubation period.

The soil was collected in a field of the CRA-SUI (Unità di Ricerca per la Suinicoltura) farm three days before the start of the experiment and sieved to $5 \mathrm{~mm}$. Soil moisture at the time of amendment incorporation was equal to $19.7 \%$, on a dry-weigh basis. Mechanical, chemical, and physico-chemical characteristics of the soil determined according to the official MiPAAF methods of soil analysis (Ministry of Agricultural, Food and Forestry Policies, 2000) on a dry-weigh basis were as follows: clay $464 \mathrm{~g} \mathrm{~kg}^{-1}$, silt $457 \mathrm{~g} \mathrm{~kg}^{-1}$ (pipette method), organic C (WalkleyBlack method) $16.0 \mathrm{~g} \mathrm{~kg}^{-1}$, Kjeldahl $\mathrm{N} 2.1 \mathrm{~g} \mathrm{~kg}^{-1}$, total $\mathrm{P} 0.87 \mathrm{~g} \mathrm{~kg}^{-1}$, organic $\mathrm{P} 0.31 \mathrm{~g} \mathrm{~kg}^{-1}$, cation exchange capacity $18.8 \mathrm{cmol} \mathrm{kg}^{-1}$ (barium chloride and triethanolamine method), total CaC03 $28 \mathrm{~g} \mathrm{~kg}^{-1}$, active $\mathrm{CaC03} 6.25 \mathrm{~g} \mathrm{~kg}^{-1}, \mathrm{pH}$ in water 8.17 .

\section{Experimental design}

The following materials were incorporated into soil: swine manure solids (LC), BC from swine manure solids (LT), wood chip (CC), BC from wood chip (CT), and compared with a non-amended control soil (Cs), each one of them with or without application of digested slurry (D) for a total of 10 treatments in a completely randomized block design with 3 replications for each treatment and measurement date (i.e. at the start of the incubation period and three months later).

Amounts of nutrients supplied to soil by BC and digestate are reported in Table 1. The amount of $\mathrm{N}$ in swine solids, not treated or thermally treated (charred), incorporated into soil $\left(0.102 \mathrm{~g} \mathrm{~N} \mathrm{~kg}^{-1}\right)$ corresponded to $170 \mathrm{~kg} \mathrm{~N} \mathrm{ha}^{-1}$; this is the maximum amount initially allowed by the EU Nitrate Directive for spreading in vulnerable areas (European Commission, 1991). The amount of supplied organic C, corresponding to this amount of $\mathrm{N}$, was $2.70 \mathrm{~g} \mathrm{C} \mathrm{kg}^{-1}$ for the non-treated swine solids and $2.46 \mathrm{~g} \mathrm{~kg}^{-1}$ for the treated swine solids (BC). The amount of $\mathrm{C}$ supplied to soil by non-treated or charred wood chip was equal to that supplied with swine solids. In this case, the amount of $\mathrm{N}$ supplied was much lower. Differences in supplied $\mathrm{C}$ between soils with and without BC (2.46 vs $\left.2.70 \mathrm{~g} \mathrm{~kg}^{-1}\right)$ are due to the fact that, in order to add the same amount of $\mathrm{N}$ to soils with $\mathrm{BC}$ from swine solids as to the non-treated swine solids $\left(0.102 \mathrm{~g} \mathrm{~kg}^{-1}\right)$, it was necessary to add a lower amount of $\mathrm{BC}$ since this nutrient in $\mathrm{BC}$ is more concentrated (from $18.2 \mathrm{~g} \mathrm{~kg}^{-1}$ total $\mathrm{N}$ in swine solids to $21.1 \mathrm{~g} \mathrm{~kg}^{-1}$ in $\mathrm{BC}$ ). The mean amount of material incorporated into soil was $5 \mathrm{~g} \mathrm{~kg}^{-1}$ dry soil, corresponding to $10 \mathrm{t} \mathrm{ha}^{-1}$, for a soil with bulk density equal to 1 (as in our laboratory vials) and in the hypothesis of incorporating the material in the top $0.2 \mathrm{~m}$ soil layer. The amount of applied digestate corresponded to $170 \mathrm{~kg} \mathrm{~N} \mathrm{ha}^{-1}$, with a total supply of $340 \mathrm{~kg} \mathrm{~N} \mathrm{ha}^{-1}$; this is the maximum amount allowed by the EU Nitrate Directive (European Commission, 1991) for non-vulnerable agricultural areas.

\section{Organic material sources}

The swine solids were collected from the pit near the CRA-SUI experimental piggeries. The wood chip was obtained by shredding shrubs collected on a river bed. They were both left to dry in the air and sieved at $1 \mathrm{~mm}$. The final moisture was equal to $10 \%$ for swine solids and $9 \%$ for wood chip.

The digested slurry was collected from the second-stage reactor of a biogas plant located near the CRA-SUI Research Unit, and stored at $4^{\circ} \mathrm{C}$ until use.

\section{Biochar preparation and composition}

We thermally treated $5 \mathrm{~g}$ dried and sieved samples of swine solids or wood chip in a confined environment (porcelain, lid-covered crucibles) at $420^{\circ} \mathrm{C}$ for $20 \mathrm{~min}$. Biochar yields were higher for swine solids than for wood chip (Table 2). The ash, total $\mathrm{N}$ and total $\mathrm{P}$ contents were much higher in $\mathrm{BC}$ from swine solids than in $\mathrm{BC}$ from wood chip. In both types of $\mathrm{OM}$, ammonium $\mathrm{N}$ nearly disappeared after the thermal treatment, leaving only organic $\mathrm{N}$. Nitric $\mathrm{N}$ was always absent from the raw material. The concentration of ashes, $\mathrm{N}$ and $\mathrm{P}$, when referred to the residual dry weight of the treated material, increased after the thermal treatment. However, when referred to the $\mathrm{OM}$ weight before thermal 
Table 1. Organic carbon, Kjeldahl nitrogen and total phosphorus contents in the amendments and in the digestate used for the experiment, and amounts supplied to soil.

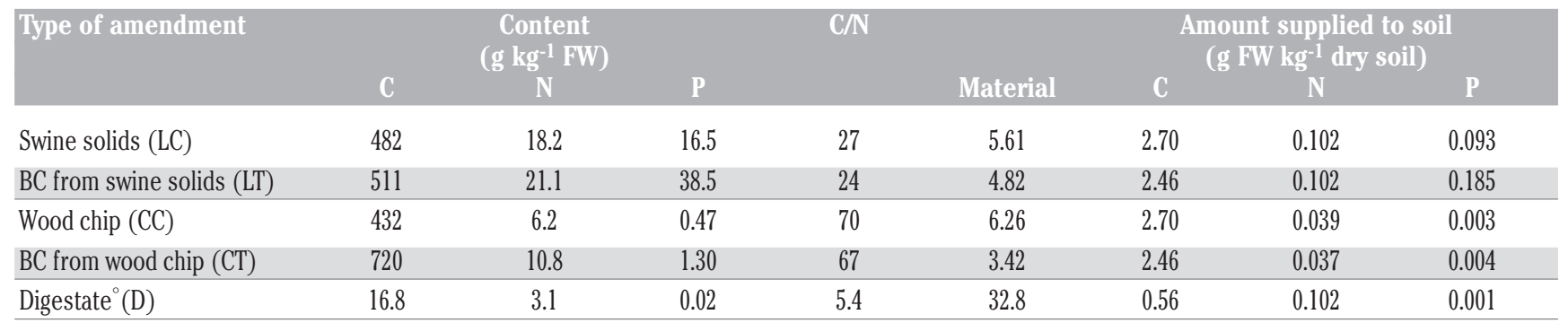

FW, weight of the organic matter used as it is (charred, non charred or D); C, carbon; $\mathrm{N}$, nitrogen; P, phosphorus; $\mathrm{BC}$, biochar; ${ }^{\circ}$ total solids (TS), $46.4 \mathrm{~g} \mathrm{~kg}{ }^{-1}$ (as it is); volatile solids, $718 \mathrm{~g} \mathrm{~kg}{ }^{-1} \mathrm{TS}^{\circ} 77 \%$ of the Kjeldahl nitrogen in digestate was constituted by ammonium $\mathrm{N}$.

Table 2. Biochar yield (as percentage of the dry weight) and main characteristics of swine solids and wood chip, before and after the thermal treatment. The residual dry weight is that of the organic amendment after thermal treatment.

\begin{tabular}{|c|c|c|c|c|c|c|}
\hline \multirow[t]{2}{*}{ Parameter } & \multicolumn{2}{|c|}{$\begin{array}{l}\text { Before treatment } \\
\text { (referred to the fresh weight) }\end{array}$} & \multicolumn{2}{|c|}{$\begin{array}{c}\text { After treatment } \\
\text { (referred to the initial DW) }\end{array}$} & \multicolumn{2}{|c|}{$\begin{array}{l}\text { After treatment } \\
\text { (referred to the residual DW) }\end{array}$} \\
\hline & Swine solids & Wood chip & Swine solids & Wood chip & Swine solids & Wood chip \\
\hline Yield (\%) & & & $40.3^{\circ}(1.38)$ & $29.4(1.73)$ & & \\
\hline Ashes $\left(\mathrm{g} \mathrm{kg}^{-1}\right)$ & $127(0.8)$ & $24 \quad(2.1)$ & $137(1.7)$ & $25(1.6)$ & 345 (11.7) & $86 \quad(2.6)$ \\
\hline Total nitrogen $\left(\mathrm{g} \mathrm{kg}^{-1}\right)$ & $18.2(0.35)$ & $5.10(0.07)$ & $8.40(0.29)$ & $3.15(0.24)$ & $21.1(0.74)$ & $10.8(0.21)$ \\
\hline Ammonium nitrogen $\left(\mathrm{g} \mathrm{kg}^{-1}\right)$ & $1.48(0.04)$ & $0.56 \quad(0.06)$ & $0.02 \quad(0.02)$ & $0.01 \quad(0.01)$ & $0.04(0.04)$ & $0.02 \quad(0.02)$ \\
\hline Organic nitrogen ${ }^{\#}\left(\mathrm{~g} \mathrm{~kg}^{-1}\right)$ & 16.7 & 4.54 & 8.38 & 3.14 & 21.1 & 10.8 \\
\hline Total phosphorus (mg kg-1) & $16.5(1.17)$ & $0.47 \quad(0.06)$ & $15.3(2.91)$ & $0.38(0.05)$ & $38.5(6.91)$ & $1.3(0.11)$ \\
\hline $\mathrm{pH}^{\S}$ & $8.0(0.01)$ & $5.85(0.06)$ & $9.65(0.04)$ & $8.80(0.07)$ & & \\
\hline
\end{tabular}

DW, dry weight. ${ }^{\circ}$ Averages of 3 replicates and standard deviation in parentheses; ${ }^{*}$ Organic nitrogen, Total nitrogen - Ammonium nitrogen; ${ }^{\S}$ measured in a 1:7 soil:water suspension, after stirring for $2 \mathrm{~h}$ and sedimentation.

treatment, the total $\mathrm{N}$ concentration decreased by $54 \%$ and by $38 \%$ for $\mathrm{BC}$ from swine solids and from wood chip, respectively, whereas there was no change in ash and total $\mathrm{P}$ content. After thermal treatment, BC from swine solids was much richer in $\mathrm{N}$ and $\mathrm{P}$ than $\mathrm{BC}$ from wood chip. The $\mathrm{pH}$ value, lower in wood chip than in swine solids, increased in both materials after charring.

\section{Organic material analyses}

The analyses of swine solids and wood chip before and after charring, and of digestate were carried out according to IPLA methods (1984). Organic C was determined by dichromate oxidation with external heating and reflux condenser; total $\mathrm{N}$ was determined with the Kjeldahl apparatus; ammonium $\mathrm{N}$ by distillation; total $\mathrm{P}$ was determined on ashes by colorimetry with ammonium molibdate after solubilization by means of $\mathrm{HCl} 1 \mathrm{~N}$.

\section{Incubation conditions}

The method proposed by Drinkwater et al. (1996) was adopted for soil incubation. For each type of amendment (CC, CT, LC, and LT), suitable amounts of organic material (Table 1) were carefully incorporated into soil and distributed in the $40 \mathrm{~mL}$ scintillation vials $(25 \mathrm{~g}$ soil in each vial). The slurry digestate was added to soil in the vials of the $+\mathrm{D}$ treatments after appropriate dilution in order to obtain the requested amount of $\mathrm{N}$ supply and to humidify soil to $60 \%$ of water-filled pore space: soil water content/soil water content at saturation $\times 100$ (WFPS). An equal amount of distilled water was added to the vials without digestate to obtain the same level of WFPS. The vials were placed in plastic boxes, together with tubes containing $\mathrm{NaOH} 4 \mathrm{~N}$ for the capture of the emitted $\mathrm{CO}_{2}$. The boxes, closed with lids, were kept in the dark in a lab- oratory incubator at $30^{\circ} \mathrm{C}$ for three months. Once a week, the vials were aerated and the moisture losses were checked and corrected. At the start and at end of the incubation period, 3 vials per treatment were frozen until analysis.

\section{Carbon dioxide release and nutrient analyses}

The $\mathrm{CO}_{2}$ released from the soil of the vials during the incubation period was trapped with $\mathrm{NaOH}$. The amount of trapped $\mathrm{CO}_{2}-\mathrm{C}$ was determined by reverse titration with $\mathrm{HCl}$ after $\mathrm{BaCl}_{2}$ addition (Rice $e t$ al., 1996). Some $\mathrm{NaOH}$ tubes, in lid-closed plastic boxes without soil, were included as blanks in the incubation experiment to remove the air $\mathrm{CO}_{2}$ content from calculations to quantify the $\mathrm{CO}_{2}$ emissions. Emissions are reported as $\mathrm{mg}$ of $\mathrm{CO}_{2}-\mathrm{C}$ released per $\mathrm{kg}$ dry soil (after subtracting air $\mathrm{CO}_{2}$ amount).

Soil mineral $\mathrm{N}\left(\mathrm{NO}_{3}-\mathrm{N}+\mathrm{NO}_{2}-\mathrm{N}+\mathrm{NH}_{4}-\mathrm{N}\right)$ was extracted from the frozen soil samples after thawing them at room temperature by using $\mathrm{KCl} 2 \mathrm{M}$ (soil/solution ratio 1:5). Nitrates were reduced to nitrites by passing them through a cadmium column; nitrites and ammonium were determined colorimetrically (with sulphanilide and dichloroisocyanuric acid, respectively) with an automatic analyzer (AutoAnalyzer 3; Bran+Luebbe GmbH, Norderstedt, Germany) according to Keeney and Nelson (1982). Plant-available P was determined colorimetrically on the sodium bicarbonate extract according to the Olsen method (Ministry of Agricultural, Food and Forestry Policies, 2000).

\section{Statistical analysis}

The Restricted Maximum Likelihood (REML) method was adopted for analysis of variance (ANOVA) according to the SAS Proc Mixed (Littell et al., 1996). In the F tests, the degrees of freedom for the 
denominator were calculated using the Kenward-Roger approximation method. Multiple comparisons of the means were carried out using the SAS LSMEANS statement and Tukey's adjustment. Factor and factor interaction effects were considered significant at $\mathrm{P}<0.05$.

\section{Results and discussion}

Significant treatment effects were detected both at the start (for $\mathrm{N}_{\min }$ and $\mathrm{P}_{\mathrm{Ols}}$; the $\mathrm{CO}_{2}-\mathrm{C}$ emissions at time 0 were zero) and at the end of the incubation period (Table 3 ).

\section{Carbon dioxide emissions and changes in soil organic carbon content}

The incorporation of organic matter into soil and digestate application had a significant effect (both the main factors and the interaction) on $\mathrm{CO}_{2}$ - $\mathrm{C}$ emissions and on changes in $\mathrm{C}_{\text {org }}$ in soil (Table 3). Three months after organic matter $(\mathrm{OM})$ incorporation, there was no significant difference in $\mathrm{CO}_{2}-\mathrm{C}$ emissions from soils amended with $\mathrm{BC}$ from wood chip (CT) or from swine solids (LT) and those measured in the control soil (Table 4), despite digestate addition. However, they were higher than those in the control soil $\left(+817 \mathrm{mg} \mathrm{C} \mathrm{kg}^{-1}\right.$ in CC and +885 $\mathrm{mg} \mathrm{C} \mathrm{kg}{ }^{-1}$ in LC) when soil had been mixed with untreated OM, with no significant difference between swine solids and wood chip. The $\mathrm{CO}_{2}-\mathrm{C}$ emissions from soil with $\mathrm{BC}$ were $48 \%$ lower than those from soil amended with non-treated OM for swine solids and $47 \%$ for wood chip.

Lower $\mathrm{CO}_{2}-\mathrm{C}$ emissions were associated with a lower reduction in the soil $\mathrm{C}_{\text {org }}$ stock (Figure 1). In particular, three months after OM incorporation, the $\mathrm{C}_{\text {org }}$ content in soils $-\mathrm{D}$ had decreased by $-2.2 \mathrm{~g} \mathrm{C} \mathrm{kg}^{-1}$ dry soil for CT $v s-4.7 \mathrm{~g} \mathrm{C} \mathrm{kg}^{-1}$ for CC, and by $-0.5 \mathrm{~g} \mathrm{C} \mathrm{kg}^{-1}$ for LT $v s-7.4$ $\mathrm{g} \mathrm{C} \mathrm{kg}^{-1}$ for LC. Therefore, it seems that the organic $\mathrm{C}$ incorporated into soil with $\mathrm{BC}$ did not mineralize, in contrast with that incorporated with the non-treated OM. These results are in agreement with those of other authors (Kuzyakov et al., 2009; Knoblauch et al., 2011). The reduction in $\mathrm{CO}_{2}-\mathrm{C}$ emissions following $\mathrm{BC}$ incorporation into soil may be attributed to a lower availability of the charred $\mathrm{OM}$ to decomposition (Schmidt and Noack, 2000). The existence of a labile C fraction in charred materials has recently been emphasized. The importance of this $\mathrm{C}$ fraction depends on feedstock type and processing conditions (intrinsic recalcitrance) but also on the pedoclimatic conditions of the soil to which it was applied (Pereira et al., 2011). A certain release of $C$ dioxide can, therefore, be expected in the short period from the decomposition of this fraction (Smith et al., 2010). However, no evidence for the presence of labile $\mathrm{C}$ was found in our experiment as the $\mathrm{CO}_{2}-\mathrm{C}$ emissions from soil amended with $\mathrm{BC}$ were not significantly higher than those in the control soil.

The supply of digestate, containing organic $\mathrm{C}$, gave rise to an increase in $\mathrm{CO}_{2}$-C emissions from soil (Table 4), in agreement with the findings of Albuquerque et al. (2011). This emission increase was not significant in the control $(\mathrm{Cs}+\mathrm{D})$ and in the BC-containing soils (CT $+\mathrm{D}$ and $\mathrm{LT}+\mathrm{D}$ ). In fact, there was no significant difference in the mean $\mathrm{CO}_{2}-\mathrm{C}$ emissions for these treatments and those of the same treatments without digestate (Cs -D, CT -D and LT -D). Also, there was no significant difference in the $\mathrm{CO}_{2}-\mathrm{C}$ emissions for the $\mathrm{CC}+\mathrm{D}$ treatment and those in CC -D. On the contrary, the addition of digestate to soil with untreated swine solids gave rise to much higher emissions than those from the same treatment without digestate; the difference between LC $+\mathrm{D}$ and $\mathrm{LC}-\mathrm{D}$ was $772 \mathrm{mg} \mathrm{C} \mathrm{kg}^{-1}$. This was 2.5 times the emission increase observed in $\mathrm{Cs}+\mathrm{D}\left(+314 \mathrm{mg} \mathrm{C} \mathrm{kg}^{-1}\right)$ with a clearly positive interaction between swine solids and digestate. Therefore, the incorpo-

Table 3. Influence of amendment incorporation and digestate application to soil on the amount of $\mathrm{CO}_{2}$ - $\mathrm{C}$ emissions in a 3-month period, on the initial mineral nitrogen $(\mathrm{N})$ and available phosphorus $(\mathrm{P})$ levels, and on $\mathrm{N}$ and $\mathrm{P}$ change after three months of incubation $(\Delta$, final - initial). ANOVA results.

\begin{tabular}{|c|c|c|c|c|}
\hline Source of variation & DF num & DF denom & F & $\operatorname{Pr}>F$ \\
\hline $\begin{array}{l}\mathrm{CO}_{2} \text {-C emission } \\
\text { Amendment } \\
\text { Digestate } \\
\text { Amendment } \times \text { digestate }\end{array}$ & $\begin{array}{l}4 \\
1 \\
4\end{array}$ & $\begin{array}{l}30 \\
30 \\
30\end{array}$ & $\begin{array}{r}33.85 \\
11.23 \\
3.90\end{array}$ & $\begin{array}{r}<0.0001 \\
0.0022 \\
0.0115\end{array}$ \\
\hline $\begin{array}{l}\Delta \mathrm{C}_{\text {org }} \\
\text { Amendment } \\
\text { Digestate } \\
\text { Amendment } \times \text { digestate }\end{array}$ & $\begin{array}{l}4 \\
1 \\
4\end{array}$ & $\begin{array}{l}10 \\
10 \\
10\end{array}$ & $\begin{array}{c}48.27 \\
7.6 \\
6.43 \\
\end{array}$ & $\begin{array}{r}<0.0001 \\
0.0202 \\
0.0079\end{array}$ \\
\hline $\begin{array}{l}\text { Initial mineral } \mathrm{N} \\
\text { Amendment } \\
\text { Digestate } \\
\text { Amendment×digestate }\end{array}$ & $\begin{array}{l}4 \\
1 \\
4\end{array}$ & $\begin{array}{l}30 \\
30 \\
30\end{array}$ & $\begin{array}{r}16.65 \\
4780.12 \\
2.58\end{array}$ & $\begin{array}{r}<0.0001 \\
<0.0001 \\
0.0573\end{array}$ \\
\hline $\begin{array}{l}\text { Initial P Olsen } \\
\text { Amendment } \\
\text { Digestate } \\
\text { Amendment×digestate }\end{array}$ & $\begin{array}{l}4 \\
1 \\
4\end{array}$ & $\begin{array}{l}30 \\
30 \\
30 \\
\end{array}$ & $\begin{array}{r}255.82 \\
128.73 \\
3.54 \\
\end{array}$ & $\begin{array}{r}<0.0001 \\
<0.0001 \\
0.0176\end{array}$ \\
\hline $\begin{array}{l}\Delta \text { mineral } \mathrm{N} \\
\text { Amendment } \\
\text { Digestate } \\
\text { Amendment } \times \text { digestate }\end{array}$ & $\begin{array}{l}4 \\
1 \\
4\end{array}$ & $\begin{array}{l}30 \\
30 \\
30\end{array}$ & $\begin{array}{l}9.1 \\
1.85 \\
0.69\end{array}$ & $\begin{array}{r}<0.0001 \\
0.1841 \\
0.6077\end{array}$ \\
\hline $\begin{array}{l}\Delta \mathrm{P} \text { Olsen } \\
\text { Amendment } \\
\text { Digestate } \\
\text { Amendment } \times \text { digestate }\end{array}$ & $\begin{array}{l}4 \\
1 \\
4\end{array}$ & $\begin{array}{l}30 \\
30 \\
30 \\
\end{array}$ & $\begin{array}{r}23.66 \\
29.75 \\
0.47 \\
\end{array}$ & $\begin{array}{r}<0.0001 \\
<0.0001 \\
0.7596\end{array}$ \\
\hline
\end{tabular}

$\mathrm{DF}$, degrees of freedom. 
ration of $\mathrm{BC}$ to soil has reduced the $\mathrm{CO}_{2}$ emissions, especially in the case of the combination $\mathrm{BC}$ from swine solids+digestate (LT +D).

The changes in the $\mathrm{C}_{\text {org }}$ stock (Figure 1 ) in the $+\mathrm{D}$ treatments did not differ from, or were lower than those in the $-\mathrm{D}$ treatments. In particular, in $\mathrm{CT}+\mathrm{D}$ the $\mathrm{C}_{\text {org }}$ decrease was lower than in $\mathrm{CT}-\mathrm{D}$, and in $\mathrm{LC}+\mathrm{D}$ it was lower than that in $\mathrm{LC}-\mathrm{D}$, whereas the $\mathrm{CO}_{2}$ - $\mathrm{C}$ emissions were higher. As far as the $\mathrm{LC}+\mathrm{D}$ treatment is concerned, we can hypothesize that, on the one hand, the $\mathrm{C}_{\text {org }}$ contained in the digestate was released into the atmosphere as $\mathrm{CO}_{2}$, without modifying (to an analytically perceivable extent) the $\mathrm{C}_{\text {org }}$ levels in soil; on the other hand, the addition of digestate may have contributed to the containment of the $\mathrm{C}_{\text {org }}$ losses from soil which occurred in the LC -D treatment during the incubation period.

\section{Changes in the mineral nitrogen content}

Slight but significant differences in the $\mathrm{N}_{\min }$ content (Table 3) were detected in soil immediately after OM incorporation and digestate application (the interaction Amendment $\times$ Digestate was not significant). In soil without digestate, the amount of $\mathrm{N}_{\text {min }}$ in the LT treatment ( $\mathrm{BC}$ from swine solids) was the same as in the control soil, Cs (10.6 vs $11.1 \mathrm{mg} \mathrm{N}$ $\mathrm{kg}^{-1}$; Table 4). This is due to the fact that the thermal treatment removed from swine solids all the $\mathrm{N}_{\text {min }}$, entirely constituted by ammonium $\mathrm{N}$, which is volatile when heated. Also, there was no significant difference in the soil with wood chip (both CC and CT) and the control soil. In soil with non-treated swine solids (LC), the $\mathbf{N}_{\min }$ content was higher than in the control soil (14.3 vs $11.1 \mathrm{mg} \mathrm{N} \mathrm{kg}^{-1}$ ), probably due to the swine solids contributing only a small amount of $\mathrm{N}_{\min }$. In soil with digestate, in all treatments the $\mathrm{N}_{\text {min }}$ levels were higher than in the same treatments without digestate, because the digestate supplied the soil with a certain amount of ammonium $\mathrm{N}$ (Table 1). Three months after the start of incubation, the $\mathrm{N}_{\min }$ levels were always higher than those at the start; in fact, the difference in $\mathrm{N}_{\min }$ Final $-\mathrm{N}_{\min }$ Initial was always positive. The
Amendment $\times$ Digestate interaction did not have any significant effect (Table 3). There was no significant difference in the change in the $\mathbf{N}_{\min }$ content of the treated soils and that in the control soil (Table 4), with the exception of the soil amended with untreated wood chip (CC). In this soil, the $\mathrm{N}_{\min }$ build-up was reduced, as had already been observed just after wood chip incorporation, probably due to the prevalence of the immobilization process over that of mineralization. Nitrogen immobilization could have been influenced by the $\mathrm{C}$ to $\mathrm{N}$ ratio. High values of the $\mathrm{C}$ to $\mathrm{N}$ ratio are usually responsible for a shift in the mineralizationimmobilization turnover toward the immobilization phase, and the $\mathrm{C}$ to $\mathrm{N}$ ratio of wood chip was equal to 70 (Table 1). However, no immobiliza-

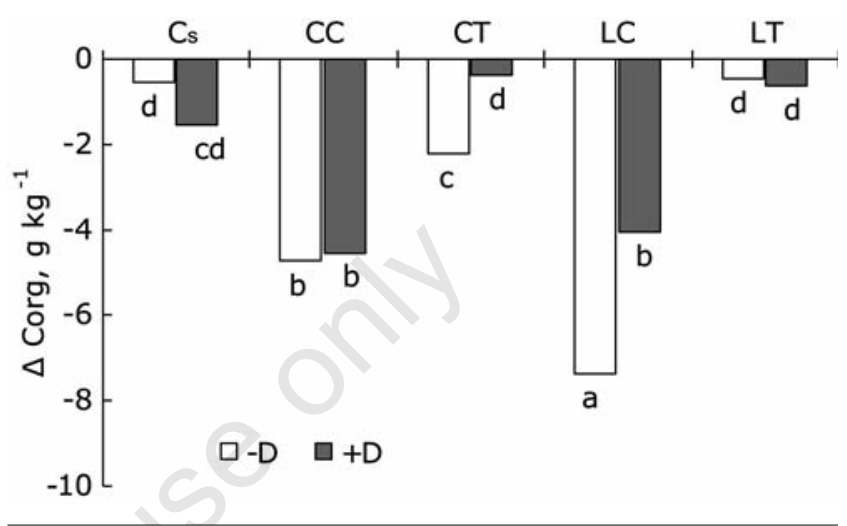

Figure 1. Change in the organic carbon $\left(\Delta \mathrm{C}_{\text {org }}\right)$ content in soil after amendment, with $(+D)$ and without $(-D)$ digestate application. Cs, control; CC, wood chip; CT, BC from wood chip; LC, swine solids; LT, BC from swine solids.

Table 4. Influence of amendment incorporation and digestate application to soil on the amount of $\mathrm{CO}_{2}-\mathrm{C}$ emissions in a 3-month period, on the initial mineral nitrogen and available phosphorus levels in soil, and on their change after three months of incubation $(\Delta$, final - initial). Mean values, referred to soil dry weight.

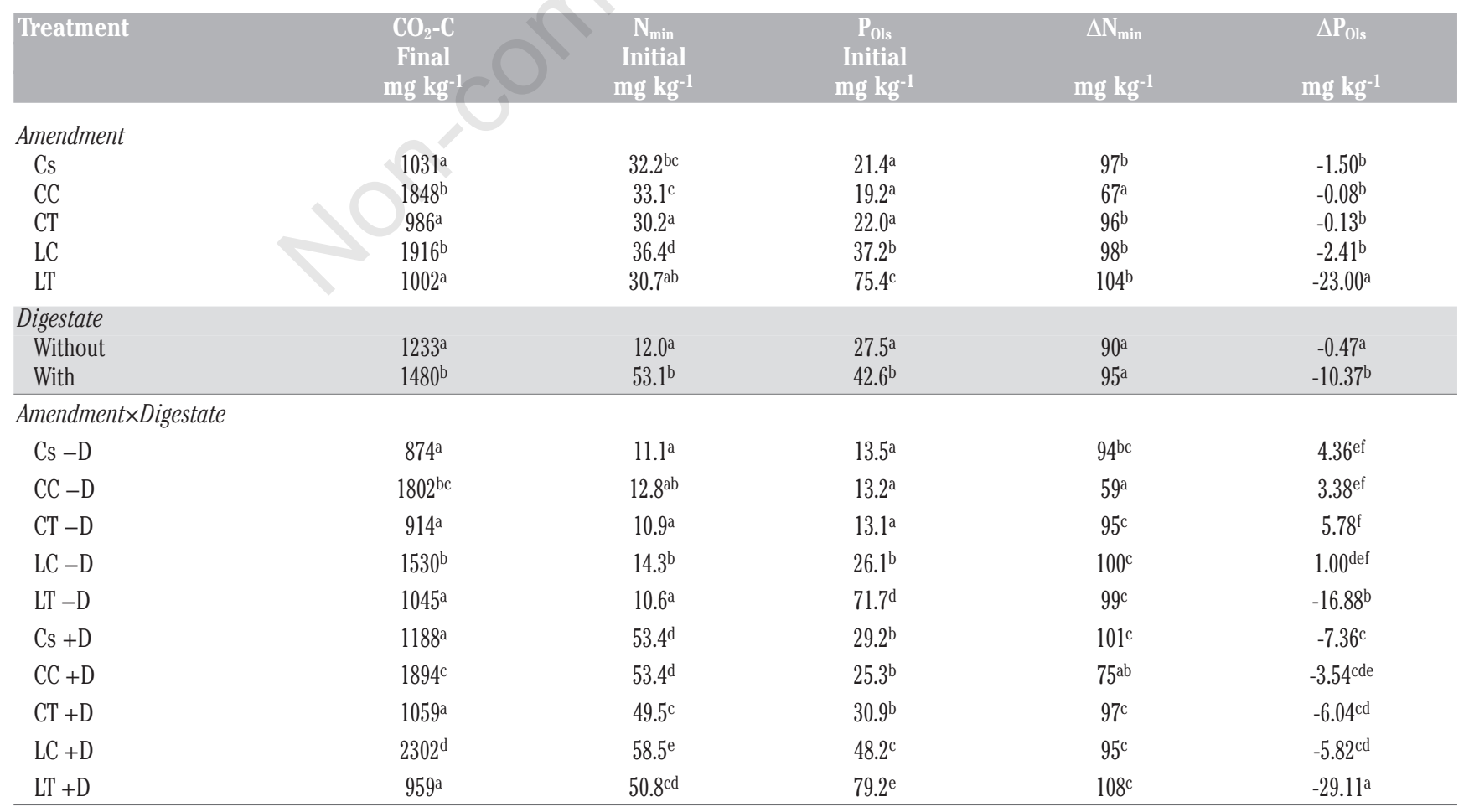

Cs, control; CC, wood chip; CT, biochar from wood chip; LC, swine solids; LT, biochar from swine solids; D, digestate. ${ }^{\text {a-f }}$ In each column, means followed by equal letters are not significantly different for P<0.05 (Tukey test). 
tion effect was detected for the CT treatment, despite its $\mathrm{C}$ to $\mathrm{N}$ ratio of 67 . The incorporation of $\mathrm{BC}$ into soil may have induced changes in soil microbial population sufficient to encourage $\mathrm{N}$ nitrification (De Luca et al., 2006) rather than immobilization.

\section{Changes in the available phosphorus content (P Olsen)}

At the start of the experiment, there were clear differences between the control and the amended soils, with or without digestate, with a significant effect of the Amendment×Digestate interaction (Table 3). Higher $\mathrm{P}_{01 \mathrm{~s}}$ amounts were detected in soil of all treatments supplying swine solids, both charred and non-charred (Table 4), mainly as a consequence of the higher amount of applied $\mathrm{P}$. In fact, for an equal amount of $\mathrm{C}$ supplied by wood chip and swine solids $\left(2.70 \mathrm{~g} \mathrm{C} \mathrm{kg}^{-1}\right.$ incorporated with the non-charred material; $2.46 \mathrm{~g} \mathrm{C} \mathrm{kg}^{-1}$ with BC; Table 1), the swine solids supplied an amount of $P$ much higher than that supplied by wood chip. Secondly, an important percentage of $P$ in the effluents consists of mineral $P$ which, when applied to soil, contributes to the reserve of available $P$ for crops (Leytem et al., 2004). In the LT treatment soil, the $\mathrm{P}_{0 \mathrm{ls}}$ content was nearly twice that of the LC treatment. In fact, since the thermal treatment increased $P$ concentration (Table 2), the weight unit of $\mathrm{BC}$ contains a higher amount of $\mathrm{P}$ than the weight unit of the untreated material. Wood chip, whether treated or not, did not contribute to soil P availability (there was no significant difference between CC or CT and control; Table 4). Besides the low amount supplied, even after concentration from the thermal treatment, it is possible that the $\mathrm{P}$ in wood chip did not contribute to the soil mineral $P$ reserve inasmuch as its nature is mainly organic.

Digestate application increased the $\mathrm{P}_{01 \mathrm{~s}}$ content in soils of all treatments by on average $15 \mathrm{mg} \mathrm{kg}^{-1}$ dry soil (SD $5.6 \mathrm{mg} \mathrm{kg}^{-1}$ ). However, differences among amended soils with digestate were similar to those in soils without digestate $(\mathrm{LT}+\mathrm{D}>>\mathrm{LC}+\mathrm{D}>\mathrm{Cs}+\mathrm{D}, \mathrm{CC}+\mathrm{D}$ and $\mathrm{CT}+\mathrm{D})$.

Three months after the start of incubation, significant effects of the Amendment $\times$ Digestate interaction were no longer detectable (Table 3 ). The $\mathrm{P}_{0 l s}$ content decreased on average in all the amended soils, especially in the LT treatment (Table 4). Since at the start of the incubation period the soil of the LT treatment contained much more $\mathrm{P}_{0 \mid \mathrm{s}}$ than the other treatments, the higher decrease observed could be related to this initial higher concentration. In general, there is a decrease in $\mathrm{P}_{\text {Ols }}$ content in soil following $\mathrm{P}$ application. It is well known that mineral $\mathrm{P}$ tends to insolubilize after incorporation into soil by different mechanisms. However, three months after the start of the experiment, the $\mathrm{P}_{01 \mathrm{~s}}$ level in the soil treated with $\mathrm{BC}$ from swine solids remained remarkably high (on average $52.4 \mathrm{mg} \mathrm{kg}^{-1}$ ).

\section{Conclusions}

These results and conclusions refer only to a short 3-month period. During this time, the incorporation of BC into a silty clay soil did not give rise to higher carbon dioxide emissions than those from the control soil, nor to a decrease in soil organic $\mathrm{C}$ content. Therefore, in agreement with results by other authors, the hypothesis that $\mathrm{C}$ supplied with $\mathrm{BC}$ rests in the soil $\mathrm{C}$ reserve is confirmed, at least over a short period. The application of digestate to soil increased carbon dioxide emissions; however, the simultaneous incorporation of $\mathrm{BC}$ into soil significantly contributed to their reduction. This is interesting because it would suggest the possibility of reducing $\mathrm{C}$ emissions from digestate when it is applied to soil for agricultural purposes by coupling digestate application and BC incorporation.

Nitrogen availability was not influenced by incorporation into soil of BC (from swine solids or wood chip) or of untreated swine solids, whereas it decreased in comparison with that in the control when untreated wood chip was incorporated into soil.

In soil with digestate, $\mathrm{BC}$ incorporation gave rise to a reduction in mineral $\mathrm{N}$ content only at the moment of digestate application; three months after the start of the experiment perceivable differences were no longer seen among soils with charred or untreated amendments. Therefore, the initial hypothesis that $\mathrm{BC}$ could trap digestate $\mathrm{N}$ does not seem sustainable.

Treatments did not influence $P$ availability; this has to be related only to the type and amount of material supplied. Given the perspective of a progressive depletion of world reserves of phosphate fertilizers, BC from swine solids that is more easily stored in terms of both time and space than non-treated swine solids appears to be an interesting source of available $\mathrm{P}$ for crops.

\section{References}

Albuquerque JA, de la Fuente C, Bernal MP, 2011. Chemical properties of anaerobic digestates affecting $\mathrm{C}$ and $\mathrm{N}$ dynamics in amended soils. Agr. Ecosyst. Environ. (In Press).

Burton CH, 2007. The potential contribution of separation technologies to the management of livestock manure. Livest. Sci. 112:208-216.

Cantrell KB, Ducey T, Ro KS, Hunt PG, 2008. Livestock waste-to-bioenergy generation opportunities. Bioresource Technol. 99:7941-7953.

Chan KY, Van Zwieten L, Meszaros I, Downie A, Joseph S, 2008. Using poultry litter biochars as soil amendments. Aust. J. Soil Res. 46: 437-444.

Collison M, Collison L, Sakrabani R, Tofield B, Wallage Z, 2009. Biochar and carbon sequestration: a regional perspective. A report prepared for East of England Development Agency (EEDA). Low Carbon Innovation Centre, University of East Anglia, Norwich, UK.

De Luca TH, MacKenzie MD, Gundale MJ, Holben WE, 2006. Soil wildfire-produced charcoal directly influences nitrogen cycling in Ponderosa Pine forests. Soil Sci. Soc. Am. J. 70:448-453.

Drinkwater LE, Cambardella CA, Reeder JD, Rice CW, 1996. Potentially mineralizable nitrogen as an indicator of biologically active soil nitrogen. In: J.W. Doran and A.J. Jones (eds.) Methods for assessing soil quality. SSSA Spec. Publ. 49, Madison, WI , USA, pp 217229.

European Commission, 1991. Council Directive 91/676/EEC of 12 December 1991 concerning the protection of waters against pollution caused by nitrates from agricultural sources. In: Official Journal, L 375, 31/12/1991, pp 1-8.

Heinberg R, Bomford M, 2009. The food and farming transition: toward a post-carbon food system. Post Carbon Institute, CA, USA. Available from: http://www.postcarbon.org/food.

IPLA, 1984. Metodi Analitici. IPLA Ed., Torino, Italy.

Keeney DR, Nelson DW, 1982. Nitrogen-inorganic forms. In: A.L. Page, R.H. Miller and D.R. Keeney (eds.) Methods of Soil Analysis. Part 2, 2nd ed. Agron. Monogr. 9, ASA and SSSA, Madison, WI, USA, pp 643698.

Knoblauch C, Maarifat AA, Pfeiffer EM, Haefele SM, 2011. Degradability of black carbon and its impact on trace gas fluxes and carbon turnover in paddy soils. Soil Biol. Biochem. 43:1768-1778.

Kuzyakov Y, Subbotina I, Chen H, Bogomolova I, Xu X, 2009. Black carbon decomposition and incorporation into soil microbial biomass estimated by 14C labeling. Soil Biol. Biochem. 41:210-219.

Lehmann J, Gaunt J, Rondon M, 2006. Bio-char sequestration in terrestrial ecosystems - A review. Mitig. Adapt. Strateg. Glob. Change 11:395-419.

Lehmann J, Joseph S, 2009. Biochar for environmental management: science and technology. Earthscan, London, UK. 
Leytem AB, Turner BL, Thacker PA, 2004. Phosphorus composition of manure from swine fed low-phytate grains: Evidence for hydrolysis in the animal. J. Environ. Qual. 33:2380-2383.

Liang B, Lehmann J, Solomon D, Kinyangi J, Grossman J, O'Neill B, Skjemstad J0, Thies J, Luizão FJ, Petersen J, Neves EG, 2006. Black carbon increases cation exchange capacity in soils. Soil Sci. Soc. Am. J. 70:1719-1730.

Littell RC, Milliken GA, Stroup WW, Wolfinger RD, 1996. SAS System for Mixed Models. SAS Inst. Inc., Cary, NC, USA.

Marchetti R, Bochicchio D, Ponzoni G, Marino A, 2010. Animal waste for pyrolysis-derived fertilizers. In: P. Sequi, D. Ferri, P. Zaccheo, E. Rea, F. Montemurro, M. Vonella and A.V. Fornaro (eds.) More sustainability in agriculture: new fertilizers and fertilization management. pp 81-87 in Proc. 18th Symp. International Scientific Centre of Fertilizers, Roma, Italy.

Ministry of Agricultural, Food and Forestry Policies, 2000. Metodi di Analisi Chimica del Suolo. Franco Angeli Ed., Milano, Italy.

Oenema 0, 2010. Biochars from digested fattening pig slurry. Proc. of the Managing livestock manure for sustainable agriculture Workshop, Wageningen, The Netherlands. Available from: http://ec.europa.eu/environment/water/workshop_manure.html

Pereira RC, Kaal J, Camps Arbestain M, Pardo Lorenzo R, Aitkenhead W, Hedley M, Macías J, Hindmarsh F, Maciá-Agulló JA, 2011. Contribution to characterisation of biochar to estimate the labile fraction of carbon. Org. Geochem. 42:1331-1342.

Rice CW, Moorman TB, Beare M, 1996. Role of microbial biomass carbon and nitrogen in soil quality. In: J.W. Doran and A.J. Jones (eds.) Methods for assessing soil quality. SSSA Spec. Publ. 49, Madison, WI , USA, pp 203-216.

Ro KS, Cantrell KB, Hunt PG, Ducey TF, Vanotti MB, Szogi AA, 2009. Thermochemical conversion of livestock wastes: Carbonization of swine solids. Bioresource Technol. 100:5466-5471.

Sánchez ME, Martínez 0, Gómez X, Morán A, 2007. Pyrolysis of mixtures of sewage sludge and manure: A comparison of the results obtained in the laboratory (semi-pilot) and in a pilot plant. Waste Manage. 27:1328-13.

Schmidt MWI, Noack AG, 2000. Black carbon in soils and sediments: analysis, distribution, implications, and current challenges. Global Biogeochem. Cycles 14:777-793.

Smith JL, Collins HP, Bailey VL, 2010. The effect of young biochar on soil respiration. Soil Biol. Biochem. 42:2345-2347.

Sohi SP, Krull E, Lopez-Capel E, Bol R, 2010. A review of biochar and its use and function in soil. Adv. Agron. 105:47-82.

Sørensen P, Rubæk GH, 2010. Availability of P and K after application of ashes and biochars from thermally-treated solid manures to soil. Proc. of the Managing livestock manure for sustainable agriculture Workshop, Wageningen, NL. Available from: http://ec.europa.eu/ environment/water/workshop_manure.html.

Steiner C, Teixeira WG, Lehmann J, Nehls T, Vasconcelos de Macêdo JL, Blum WEH, Zech W, 2007. Long term effects of manure, charcoal and mineral fertilization on crop production and fertility on a highly weathered Central Amazonian upland soil. Plant Soil 291:275- 